\title{
\begin{tabular}{l|l} 
Mibraries & DSpace@MIT
\end{tabular}
}

\author{
MIT Open Access Articles
}

Bacteriohopanepolyols along redox gradients in the Humboldt Current System off northern Chile

The MIT Faculty has made this article openly available. Please share how this access benefits you. Your story matters.

Citation: Matys, E. D. et al. "Bacteriohopanepolyols along redox gradients in the Humboldt Current System off northern Chile." Geobiology 15, 6 (August 2017): 844-857 @ 2017 John Wiley \& Sons Ltd

As Published: http://dx.doi.org/10.1111/gbi.12250

Publisher: Wiley

Persistent URL: https://hdl.handle.net/1721.1/128453

Version: Author's final manuscript: final author's manuscript post peer review, without publisher's formatting or copy editing

Terms of use: Creative Commons Attribution-Noncommercial-Share Alike 


\section{Bacteriohopanepolyols along redox gradients in the Humboldt Current System}

\section{off northern Chile}

Emily MATYS ${ }^{1 *}$, Julio SEPÚLVEDA ${ }^{2 *}$, Silvio PANTOJA ${ }^{3}$, Carina B. LANGE ${ }^{3}$, Magaly CANIUPÁN $^{3}$, Frank LAMY ${ }^{4}$, and Roger E. SUMMONS ${ }^{1}$

1. Department of Earth, Atmospheric, and Planetary Sciences, Massachusetts Institute of Technology, 77 Massachusetts Avenue, Cambridge, MA 02139, USA

2. Department of Geological Sciences, Institute of Arctic and Alpine Research (INSTAAR), University of Colorado Boulder, Boulder, CO, USA

3. Department of Oceanography and COPAS Sur-Austral, University of Concepción, Concepción, Chile

4. Alfred Wegener Institute for Polar and Marine Research (AWI), Bremerhaven, Germany

*To whom correspondence should be addressed: ematys@mit.edu (E.M.); jsepulveda@colorado.edu (J.S.)

*To whom correspondence should be addressed: Author

Keywords: bacteriohopanepolyols, bacteriohopanetetrol isomer, anammox, oxygen minimum zone, Chile 


\section{Abstract}

Marine oxygen minimum zones (OMZs) are characterized by the presence of subsurface suboxic or anoxic layers where diverse microbial processes are responsible for the removal of fixed nitrogen. OMZs have expanded over past decades and are expected to continue expanding in response to the changing climate, while the implications for marine biogeochemistry, particularly nitrogen cycling, are uncertain. Cell membrane lipids (biomarkers), such as bacterial bacteriohopanepolyols (BHPs) and their degradation products (hopanoids), have distinctive structural attributes that convey information about their biological sources. Since the discovery of fossil hopanoids in ancient sediments, the study of BHPs has been of great biogeochemical interest due to their potential to serve as proxies for bacteria in the geological record. A stereoisomer of bacteriohopanetetrol (BHT), BHT II, has been previously identified in OMZ waters, and has since been unequivocally identified in culture enrichments of anammox bacteria, a key group contributing to nitrogen loss in marine OMZs. We tested BHT II as a proxy for suboxia/anoxia and anammox bacteria in suspended organic matter across OMZ waters of the Humboldt Current System off northern Chile, as well as in surface and deeply buried sediments (125-150 ky). The BHT II ratio (BHT II/total BHT) increases as oxygen content decreases through the water column, consistent with previous results from Perú, the Cariaco Basin and the Arabian Sea, and in line with microbiological evidence indicating intense anammox activity in the Chilean OMZ. Notably, BHT II is transported from the water column to surface sediments, and preserved in deeply buried sediments, where the BHT II ratio correlates with changes in $\delta^{15} \mathrm{~N}$ sediment values 
during glacial-interglacial transitions. This study confirms that BHT II offers a proxy for past changes in the relative importance of anammox, and fluctuations in nitrogen cycling in response to ocean redox changes through the geological record.

\section{Introduction}

The consequences of a reduction in dissolved $\mathrm{O}_{2}$ on the structure of marine ecosystems, biological and biogeochemical processes, ocean management, and sustainable fisheries remain uncertain. Thus, the study of microbial processes in oxygen minimum zones (OMZs) — dynamic regions of the modern ocean characterized by the presence of subsurface sub-oxic to anoxic waters, such as in the Eastern Tropical South Pacific (ETSP) off northern Chile is critical to better understand how they may respond to future scenarios of environmental change. OMZs are operationally defined as water masses with $<20 \mu \mathrm{mol} \mathrm{O} / 2 \mathrm{~kg}$ water. This is the maximum $\mathrm{O}_{2}$ level at which the use of alternate electron acceptors has been reported (Smethie, 1987). OMZs comprise $\sim 1-7 \%$ (v/v) of the global ocean (Wright et al., 2012), occurring in the Pacific Ocean, the Atlantic Ocean, and the Arabian Sea, particularly along continental margins where the wind-driven upwelling of nutrient-rich waters sustains enhanced marine productivity and microbial respiration (Paulmier and Ruiz-Pino, 2009). In poorly ventilated regions, respiratory $\mathrm{O}_{2}$ demand during degradation of organic matter exceeds $\mathrm{O}_{2}$ availability leading to the development of sub-oxic $\left(1-20 \mu \mathrm{mol}_{2} / \mathrm{kg}\right.$ water $)$ to essentially anoxic $\left(<1 \mu \mathrm{mol} \mathrm{O}_{2} / \mathrm{kg}\right.$ water) regions at mid-water depths (Wright et al., 2012). OMZs are inhospitable to most metazoans but are instead dominated by prokaryotes and microaerobic unicellular eukaryotes (Ulloa et al., 2012; Wright et al., 2012; Capone and Hutchins, 2013). In fact, these areas support thriving microbial communities that cycle organic and inorganic nutrients such as nitrogen through aerobic and anaerobic processes, making a significant contribution to the productivity and microbial biogeochemistry of the 
modern global ocean (Stevens and Ulloa 2008; Capone and Hutchins, 2013). Nitrogen can be a limiting nutrient for biological production and shapes the biogeochemistry and microbial ecology of OMZs. Nitrate is actively reduced to nitrite, which is further converted to $\mathrm{N}_{2}$ gas through heterotrophic denitrification and the autotrophic anaerobic oxidation of ammonium (anammox) process, or to ammonium through dissimilatory nitrate reduction (Lam and Kuypers, 2011; Thamdrup, 2012). Pelagic and coastal OMZs have expanded over the last five decades and are expected to continue expanding under global warming conditions (Stramma et al., 2008), which includes an increase in sea surface temperature and thermal stratification, further reducing $\mathrm{O}_{2}$ solubility and ocean ventilation (Bograd et al., 2008; Stramma et al., 2008; Keeling et al., 2010). However, the effect of OMZ expansion on nitrogen cycling remains unclear.

Present-day and past changes in marine oxygenation (e.g., OMZ extension and intensity) and nitrogen cycling may be studied using molecular biomarkers found in oxygen-depleted waters and preserved in the geological record. Molecular biomarkers are natural products that may serve as proxies for biological sources, biogeochemical processes, microbial metabolisms, and environmental conditions (Summons and Lincoln, 2012; Newman et al., 2016). Bacteriohopanepolyols (BHPs) comprise a structurally diverse group of bacterial pentacyclic triterpenoids and a biomarker class that is widely used for environmental, paleoceanographic and paleo-reconstruction studies (Talbot and Farrimond, 2007; Wakeham et al., 2012; Blumenberg et al., 2013). Since the discovery of their fossil counterparts in ancient sediments (Ourisson et al., 1979), hopanoids and their biological precursors (BHPs) have been of great interest for their potential to serve as proxies for bacteria in the geological record (Brocks and Summons, 2003). Interpreting the significance of particular sedimentary hopanoids, however, is presently hampered by an incomplete understanding of their phylogenetic associations, biological functions, and spatial and temporal disposition within the environment (e.g., Newman et al., 2016). 
BHPs are biosynthesized by a wide variety of aerobic aquatic and soil bacteria including heterotrophs, methanotrophs, methylotrophs, cyanobacteria and purple non-sulfur bacteria (Rohmer et al., 1984; Farrimond et al., 1998; Summons et al., 1999; Talbot and Farrimond, 2007). They are also produced by diverse anaerobes, both obligate and facultative, that include anaerobic ammonium oxidizing bacteria, sulfate-reducing bacteria, Planctomycetes and Geobacter sp. (Sinninghe Damsté et al., 2004; Fischer et al., 2005; Hartner et al., 2005; Blumenberg et al., 2006; Rattray et al., 2008; Eickhoff et al., 2013, Rush et al., 2014). BHPs may serve a variety of physiological functions (Pearson et al., 2009), including the regulation of membrane permeability and fluidity, lipid ordering, and membrane compartmentalization (Doughty et al., 2009: Welander et al., 2009; Sáenz et al., 2012, 2015). Environmental conditions appear to be a significant factor affecting BHP diversity (Rashby et al., 2007; Talbot and Farrimond 2007; Cooke et al., 2008; Pearson et al., 2009; Ricci et al., 2014), with changes in temperature, salinity, $\mathrm{pH}$, light intensity, redox potential, nutrients, and oxygen concentrations prompting the production of particular BHP structures in different bacterial groups (Talbot et al., 2003). However, the exact environmental mechanisms controlling the chemical diversity and composition of BHPs, as well as their role in cellular physiology are topics of continuing study.

Marine environments are of particular interest for the study of BHPs given the prevalence of hopanoid hydrocarbons in ancient marine sediments and petroleum, and the paucity of studies that have directly measured intact BHPs in the marine water column and sediments (Blumenberg et al., 2007; Pearson et al., 2007; Wakeham et al., 2007; Sáenz et al., 2011; Kharbush et al., 2013). BHPs previously identified in marine waters include bacteriohopanetetrol (BHT), a putative BHT stereoisomer (BHT II), a C-2 methylated homologue of BHT (2-MeBHT), aminobacteriohopanetriol (aminotriol), $\Delta 6 / 11$ unsaturated aminotriol, aminobacteriohopanetetrol (aminotetrol), aminobacteriohopanepentol (aminopentol), $\Delta 6 / 11$ unsaturated aminopentol, bacteriohopanepentol (BHpentol), hopane 
ribonolactone (lactone), anhydrobacteriohopanetetrol (anhydroBHT), ribonyl hopane, and adenosylhopane.

So far, BHT II has been identified exclusively in OMZ waters of the Eastern Tropical Pacific, Cariaco Basin, and the Arabian and Baltic Seas (Sáenz et al., 2011; Wakeham et al., 2012; Kharbush et al., 2013; Berndmeyer et al., 2014), which suggests that this isomer may be one of the few marine BHP structures with a unique environmental pattern and the potential to be developed as a biomarker for modern and ancient water column hypoxia/anoxia (Sáenz et al., 2011; Kharbush et al., 2013). Although its phylogenetic association was unknown at that time, it was suggested that a 'BHT II ratio' (BHT II/total BHT) could serve as a useful proxy for suboxic to anoxic conditions (Sáenz et al., 2011). More recently, BHT II was unequivocally identified in culture enrichments of the anammox bacterium 'Candidatus Scalindua profunda' and in sediments from Golfo Dulce, an anoxic marine fjord-like enclosure, at depths where anammox bacteria proliferate (Rush et al., 2014). Notably, the distribution of BHT II in Gulfo Dulce sediment cores closely tracks the distribution of ladderane fatty acids (Rush et al., 2014), unique biomarkers for anammox bacteria (Sinninghe Damsté et al., 2002). This is consistent with a study of the water column of the anoxic and sulfidic Cariaco Basin, which revealed that the greatest concentrations of ladderane fatty acids and BHT II co-occurred at the chemocline (Wakeham et al., 2012). Ladderane lipids have been successfully used as biomarkers for the anammox process (Sinninghe Damsté et al., 2002; Kuypers et al., 2003; Jaeschke et al., 2009). Although ladderane lipids have been detected in Pleistocene ( 140 ka) marine sediments (Jaeschke et al., 2009), these lipids are thermally unstable (Jaeschke et al., 2008) and their degradation products have not yet been reported in ancient sediments (Rush et al., 2014). Unlike ladderane lipids, intact BHPs have been reported in sediments as old as the Jurassic (Bednarczyk et al., 2005) and their recalcitrant carbon skeletons are stable in sedimentary records over timescales of up to 1.64 Ga (e.g., Summons et al., 1988). In fact, BHT II has been detected in ancient saproprel sediments (2.6 Ma; Rush et al., 2015), which suggests that BHT II may serve as a proxy for 
anammox bacteria over much longer time scales than is currently possible using ladderane lipids.

In this study, we analyzed the distribution and diversity of BHPs in water column samples, surface sediments, and deeply buried sediments from the Humboldt Current System off the coast of northern Chile. We particularly focused on the distribution of BHT and BHT II, with depth and along a latitudinal gradient of oxygenation within the OMZ of the ETSP to validate its use as a biomarker for anammox activity in the water column and in paleoceanographic archives. Our results confirm that the production, transport, and preservation of BHT II affords a window into past changes in the relative abundance of anammox and, thus, fluctuations in nitrogen cycling during periods of ocean redox variability.

\section{Methods}

\subsection{Study area}

The Eastern Tropical South Pacific (ETSP) contains one of the three major permanent OMZs in the modern global ocean. The OMZ persists within the Humboldt Current System, a major upwelling system that extends from northern Peru and Ecuador $\left(\sim 4^{\circ} \mathrm{S}\right)$ to southern Chile ( $\sim 45^{\circ} \mathrm{S}$; Montecino and Lange, 2009), accounting for approximately $11 \%(\mathrm{v} / \mathrm{v})$ of the global OMZ volume (Fuenzalida et al., 2009). The water column in this OMZ system is characterized by steep $\mathrm{O}_{2}$ gradients (oxyclines) from dysoxic $\left(20-90 \mu \mathrm{mol} \mathrm{O}_{2} / \mathrm{kg}\right.$ water) to suboxic conditions above and below the anoxic core. The $\mathrm{OMZ}$ is strong and more persistent off Perú and northern Chile, more dynamic in the central-south, and more pronounced near the coast than further offshore (Paulmier et al., 2006). Low oxygen levels in this area are maintained through the combination of high primary productivity $\left(9 \mathrm{gC} / \mathrm{m}^{2} /\right.$ day; Daneri et al., 2000), decomposition of sinking organic material (Chavez and Messie, 2009), and weak circulation (Bettencourt et al., 2015). Suboxic to anoxic conditions within the OMZ core (Canfield et al., 2010; Ulloa et al., 2012) prompt the development of a dynamic nitrogen cycle (Thamdrup, 2012). Previous studies have identified anammox as a significant pathway of 
nitrogen $(\mathrm{N})$ loss in OMZs and the dominant pathway in the ETSP, considerably outpacing denitrification at the top of the OMZ core (Lam et al., 2009; Canfield et al., 2010; Thamdrup, 2012).

\subsection{Sample collection}

Water column, surface sediment, and subsurface sediment samples were collected during three oceanographic cruises carried on during austral winter (MOOMZ-2) and spring (ChiMeBo, BiG RAPA) in the Humboldt Current System, off the coast of northern Chile between $20.1^{\circ} \mathrm{S}$ and $30.2^{\circ} \mathrm{S}$, following a bathymetrical and latitudinal gradient of oxygenation (Table 1; Figure 1).

\subsubsection{ChiMeBo Cruise}

The R/V SONNE University of Bremen expedition ChiMeBo (Cruise SO-211) collected samples along the Chilean continental slope between the cities of Valparaíso $\left(\sim 33^{\circ} \mathrm{S}\right)$ and Antofagasta $\left(223.5^{\circ} \mathrm{S}\right)$ during austral spring (November 2-29) in 2010 (Hebbeln et al., 2011). Three water column profiles along the Chilean continental slope were examined in this study, off Taltal $\left(25^{\circ} \mathrm{S}\right)$, off Copiapó $\left(27.5^{\circ} \mathrm{S}\right)$, and off Coquimbo $\left(30.2^{\circ} \mathrm{S}\right.$; Table 1$)$. At the time of the cruise, the OMZ core in the studied region spanned $\sim 80-350 \mathrm{~m}$ in depth. About $40-100 \mathrm{~L}$ of seawater was collected from 3-4 water depths at each station covering oxic surface waters $(\sim 10 \mathrm{~m})$, anoxic subsurface waters $(\sim 60-240 \mathrm{~m})$, and oxic deep waters $(\sim 850-1200 \mathrm{~m})$ using a rosette equipped with Niskin bottles. Seawater was transferred to darkened carboys, and particulate organic mater (POM) was filtered onboard through pre-combusted glass fiber filters (47 mm, $0.7 \mu \mathrm{m}$, Millipore) using a peristaltic pump, and kept frozen at $-20{ }^{\circ} \mathrm{C}$ until extraction in the laboratory.

Surface sediments (top $0-1 \mathrm{~cm}$ of sediment core) from the Chilean continental margin were sampled at a total of 7 stations between $\sim 23.5^{\circ} \mathrm{S}$ and $\sim 27.5^{\circ} \mathrm{S}$ off the coast of the cities of Antofagasta and Copiapó, respectively (Table 1; Hebbeln et al., 2011). A multi-corer (MUC) 
equipped with eight large $(10 \mathrm{~cm}$ diameter $)$ and four small $(6 \mathrm{~cm}$ diameter $)$ acrylic glasscoring tubes of $60 \mathrm{~cm}$ in length was used to obtain sediment samples with an undisturbed surface layer. Cores were extruded and subsampled onboard at 1-cm resolution and kept frozen at $-20{ }^{\circ} \mathrm{C}$ until extraction in the laboratory. Two sites were sampled along the Antofagasta transect $\left(\sim 23.5^{\circ} \mathrm{S}\right)$, characterized by a steep upper slope and shallow-water plateaus with no recent sedimentation (15012 and 15011). Two sites were sampled on the Taltal transect $\left(\sim 25^{\circ} \mathrm{S}\right)$. The site at $920 \mathrm{~m}$ (GeoB 15007) is related to a sediment drift body. The site at $539 \mathrm{~m}$ (GeoB 15008) was located in a depression on a SE-NW trending ridge. Three sites were sampled along the Copiapó transect $\left(\sim 27.5^{\circ} \mathrm{S}\right)$. The slope angle in this area is lower than in the other sampling areas. Therefore, the probability for sediment deposition is significantly higher in sites 15004, 15005, and 15022.

In addition to surface sediments, subsurface sediments were collected using the seafloor drill rig MARUM-MeBo from the University of Bremen (Table 1). This study describes a small

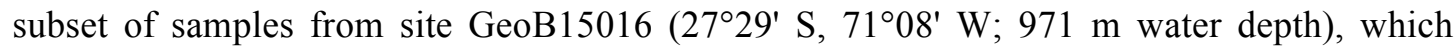
correspond to Glacial Termination II, or the transition from Marine Isotope Stages 6 to 5 ( 120-150 ky; Martínez-Méndez et al., 2013).

\subsubsection{BiG RAPA Cruise}

The R/V Melville C-MORE expedition BiG RAPA (Biogeochemical Gradients: Role in Arranging Planktonic Assemblages) collected samples between Iquique $\left(20.2^{\circ} \mathrm{S}, 70.1^{\circ} \mathrm{W}\right)$ and Rapa Nui (Easter Island; 27.1 ${ }^{\circ} \mathrm{S}, 109.3^{\circ} \mathrm{W}$ ), Chile during austral spring (November 18December 14) in 2010 (Table 1). This study describes samples from a water column profile collected at Station 1, which spanned the OMZ structure off the coast of Iquique $\left(20.3^{\circ} \mathrm{S}\right)$. At the time of the cruise, the OMZ core in the studied region spanned $\sim 50-530 \mathrm{~m}$ in depth. POM was collected from six water depths $(0,30,40,65,200$, and $1900 \mathrm{~m})$ extending from the photic zone, across the oxycline, through the $\mathrm{OMZ}$ core and below using a rosette equipped with Niskin bottles. Samples of $\sim 200 \mathrm{~L}$ were transferred to darkened carboys, filtered onboard 
through pre-combusted glass fiber filters ( $0.7 \mu \mathrm{m}$, Millipore) using a peristaltic pump, and kept frozen at $-20{ }^{\circ} \mathrm{C}$ until extraction in the laboratory. No sediment samples were collected during this cruise.

\subsubsection{MOOMZ-2 Cruise}

The R/V AGOR Vidal Gormáz Agouron expedition MOOMZ-2 collected samples off the coast of Iquique, Chile $\left(20.2^{\circ} \mathrm{S}, 70.1^{\circ} \mathrm{W}\right)$ during austral winter (August) in 2009 (Alarcón and Ulloa, 2009; Table 1). This study describes samples from a water column profile collected at Station 3, which spanned the OMZ structure off the coast of Iquique $\left(20.3^{\circ} \mathrm{S}\right)$. At the time of the cruise, the OMZ core in the studied region spanned $\sim 58-480 \mathrm{~m}$ in depth. Two WTS-LV08 McLane Laboratories in situ pumps were used in tandem to provide a continuous stream of seawater to be filtered along a high-resolution profile. POM was collected from 9 depths $(10,25,50,70,110,200,300,450$ and $600 \mathrm{~m})$ extending from the photic zone, across the oxycline, through the $\mathrm{OMZ}$ core and below at Station 3. Seawater was fractionated into two size classes $(0.3-3 \mu \mathrm{m}$ and $>3 \mu \mathrm{m})$ using a $3.0 \mu \mathrm{m} 142 \mathrm{~mm}$ diameter glass fiber filter (Pall) as a pre-filter, and a $0.3 \mu \mathrm{m} 142 \mathrm{~mm}$ diameter glass fiber filter (Sterlitech). This approach allows us to characterize the biomarker composition of $\mathrm{POM}>3.0 \mu \mathrm{m}$, assumed to represent particle-associated microorganisms and marine aggregates, and of a fine fraction of 0.3-3.0 $\mu \mathrm{m}$ assumed to mostly represent free-living microorganisms and small suspended particles (Karl et al., 1988). Filters were kept frozen at $-20{ }^{\circ} \mathrm{C}$ until extraction in the laboratory. No sediment samples were collected during this cruise.

\subsection{Lipid extraction}

Frozen surface sediment and water column filters were placed in combusted glass centrifuge vials and spiked with $40 \mathrm{ng}$ of $\mathrm{C}_{16} \mathrm{PAF}$ as a recovery standard. Total lipid extracts (TLEs) were obtained by extracting the samples using a modified Bligh and Dyer method (Bligh and Dyer, 1959) as reported by Sturt et al. (2004). Dichloromethane (DCM) was used in place of chloroform. Samples were extracted by ultrasonication (30 mins at room temperature) first 
(2x) using a mixture of methanol/dichloromethane/phosphate buffer solution $(2: 1: 0.8, \mathrm{v} / \mathrm{v} / \mathrm{v})$, and then $(2 \mathrm{x})$ using a mixture of methanol/dichloromethane/1\% trichloroacetic acid in water $(2: 1: 0.8, \mathrm{v} / \mathrm{v} / \mathrm{v}))$. After each extraction the vials were centrifuged at $3000 \mathrm{rpm}$ for 15 minutes, and the supernatants were transferred to different separatory funnels (phosphate buffer vs. trichloroacetic acid). Supernatants were then subjected to liquid-liquid extractions using $5 \mathrm{~mL}$ of dichloromethane and water. The organic layers were collected as separated TLEs, dried under a gentle stream of $\mathrm{N}_{2}$, and then combined into one final TLE. The extraction with a phosphate buffer solution was used to maximize the extraction of bacterial membrane lipids, while the extraction with trichloroacetic acid (TCA) was used to maximize the extraction of more recalcitrant cellular structures (i.e. archaeal membrane lipids; Nishihara and Koga, 1987). However, since it has been shown that TCA can accelerate the degradation of BHPs (Sáenz, 2010), both extraction procedures were not combined until the TCA was removed from the samples. The TLEs were kept frozen at $-20{ }^{\circ} \mathrm{C}$ until analysis. Additionally, freeze dried subsurface sediment samples from core GeoB15016 were extracted (3x) using an Accelerated Solvent extraction system (DIONEX ASE 200) and a solvent mixture of DCM:MeOH 9:1 (static time of 5 min at $100^{\circ} \mathrm{C}$ ).

\subsection{High Performance Liquid Chromatography - Atmospheric Pressure Chemical Ionization}

- Mass Spectrometry analysis

A fraction of each TLE was acetylated with pyridine/acetic anhydride $(1: 1, \mathrm{v} / \mathrm{v})$ at $70{ }^{\circ} \mathrm{C}$ for 1 $\mathrm{h}$ and left at room temperature overnight. The acetylated TLEs were analyzed by highperformance liquid chromatography- atmospheric pressure chemical ionization - mass spectrometry (HPLC-APCI-MS). The LC-MS system comprised a 1200 Series HPLC (Agilent Technologies, Santa Clara, CA, USA) equipped with an auto sampler and a binary pump linked to a Q-TOF 6520 mass spectrometer (Agilent Technologies) via an APCI interface operated in positive ion mode (Welander et al., 2012). A Poroshell 120 EC-C 18 column ( $2.1 \times 150 \mathrm{~mm}, 2.7 \mu \mathrm{m}$; Agilent Technologies) was chosen to provide fast and highresolution separations of a wide range of small molecules at lower pressures. The column 
temperature was set at $30^{\circ} \mathrm{C}$. The eluent flow remained constant at $0.19 \mathrm{ml} / \mathrm{min}$ throughout the analysis. Eluent A contained a mixture of methanol: $\mathrm{H}_{2} \mathrm{O} 95: 5 \mathrm{v} / \mathrm{v}$ and eluent $\mathrm{B}$ comprised pure isopropyl alcohol (IPA). The HPLC gradient was as follow: isocratic flow of $100 \%$ eluent A (0-2 mins), a linear gradient from $0-20 \%$ of eluent B (2-20 mins), isocratic flow of 20\% B (20-30 mins), a linear gradient from $20-30 \%$ of eluent B (30-40 mins), a linear gradient from $30-0 \%$ B (40-45 mins), isocratic flow of $0 \%$ B for 5 minutes. The column was conditioned for 5 minutes of post-run time at $0 \% \mathrm{~B}$. The APCI parameters were as follows: gas temperature $325^{\circ} \mathrm{C}$, vaporizer temperature $350^{\circ} \mathrm{C}$, drying gas $\left(\mathrm{N}_{2}\right)$ flow $61 /$ min, nebulizer $\left(\mathrm{N}_{2}\right)$ flow $30 \mathrm{l} / \mathrm{min}$, capillary voltage $1200 \mathrm{~V}$, corona needle $4 \mu \mathrm{A}$, and fragmentor $150 \mathrm{~V}$. BHPs were identified on the basis of accurate mass measurements of their protonated molecular ions, fragmentation patterns in MS-MS mode, and by comparison of relative retention times (Talbot et al., 2003, 2007; Welander et al., 2012). Quantification was achieved through an external standard curve of $3 \alpha, 12 \alpha$-Dihydroxy-5 $\beta$-pregnan-20-one,3,12-diacetate. This compound was chosen as an internal standard because of its structural similarity to hopanoids and because it has a retention time that does not overlap with the range of BHPs of interest.

\subsection{Stable nitrogen isotope analysis of bulk sediment}

The stable nitrogen isotope composition $\left(\delta^{15} \mathrm{~N}\right)$ of bulk sediment $(\sim 25 \mathrm{mg})$ was determined on triplicate samples using a Fisons (Carlo Erba) NA 1500 elemental analyzer fitted with a Costech Zero Blank Autosampler and coupled to a Thermo Finnigan Delta Plus XP isotope ratio mass spectrometer. Analytical reproducibility $(1 \sigma)$ was calculated as better than $0.5 \%$. Acetanilide and urea (Arndt Schimmelmann, Indiana University), and $\mathrm{IAEA}^{-\mathrm{NO}_{3}}$ (Potassium nitrate) and IAEA-N-2 (ammonium sulfate) of known isotopic composition were used as standards.

\section{Results and Discussion}

\subsection{Biogeochemical structure of the Humboldt Current System off northern Chile}


Cross sections for the Humboldt Current System are shown in Figure 2. Temperature, salinity, and dissolved oxygen concentrations were measured at all five stations, located along the Chilean coast between $20.1^{\circ} \mathrm{S}$ and $30.2^{\circ} \mathrm{S}$. Note that the hydrographic profiles were obtained during three different cruises and different dates.

Dissolved oxygen concentrations in surface waters $(10 \mathrm{~m})$ ranged from $150 \mu \mathrm{mol} \mathrm{O}_{2} / \mathrm{kg}$ water at $30.2^{\circ} \mathrm{S}$ to $260 \mu \mathrm{mol} \mathrm{O}_{2} / \mathrm{kg}$ water at $20.1^{\circ} \mathrm{S}$ (Figure 2). The underlying OMZ structure is comprised of an upper oxycline (transition from oxygenated surface waters to the upper OMZ region), an $\mathrm{OMZ}$ core $\left(\mathrm{O}_{2}\right.$ concentrations $<20 \mu \mathrm{mol} / \mathrm{kg}$ water), and a deep oxycline (transition from the bottom of the OMZ to abyssal waters; Wright et al., 2012; Bettencourt et al., 2015). The OMZ core extended from approximately 50 to $500 \mathrm{~m}$ at $20.1^{\circ} \mathrm{S}$ and from 50 to $400 \mathrm{~m}$ at $30.2^{\circ} \mathrm{S}$. The minimum dissolved oxygen concentrations measured throughout the $\mathrm{OMZ}$ core ranged from $3.2 \mu \mathrm{mol} \mathrm{O}_{2} / \mathrm{kg}$ water at $30.2^{\circ} \mathrm{S}$ to $0.9 \mu \mathrm{mol} \mathrm{O}_{2} / \mathrm{kg}$ water at $20.1^{\circ} \mathrm{S}$. Generally, the depth of the upper OMZ limit remained constant at $\sim 50$ to $60 \mathrm{~m}$. However, the minimum dissolved oxygen concentration and width of the OMZ core are related to latitude, with lower dissolved oxygen concentrations, and a more expansive and persistent OMZ structure existing in the northernmost portion of the sampling region. These measurements parallel previous studies of the ETSP (Farías et al., 2007; Canfield et al., 2010).

Nutrient measurements were obtained throughout the water column at $20.3^{\circ} \mathrm{S}, 70.8^{\circ} \mathrm{W}$ during expedition BiG RAPA and are freely available on online on the C-MORE website (http://hahana.soest.hawaii.edu/cmorebigrapa/bigrapa.html; Figure 3). Nitrate $\left(\mathrm{NO}_{3}{ }^{-}\right)$, the predominant form of bioavailable inorganic nitrogen in the ocean, was measured in highest concentration throughout the $\mathrm{OMZ}$ structure, reaching a maximum $\left(39.6 \mu \mathrm{mol} \mathrm{NO}_{3}{ }^{-} / \mathrm{kg}^{-6}\right.$ water) at $60 \mathrm{~m}$, followed by a decrease (to $15 \mu \mathrm{mol} \mathrm{\textrm {NO } _ { 3 }}{ }^{-} / \mathrm{kg}$ water), and a secondary maximum at $350 \mathrm{~m}\left(>40 \mu \mathrm{mol} \mathrm{NO}_{3}{ }^{-} / \mathrm{kg}\right.$ water $)$. Nitrite oxidation by autotrophic and heterotrophic bacteria is a primary source of oceanic $\mathrm{NO}_{3}{ }^{-}$and the likely source of $\mathrm{NO}_{3}{ }^{-}$in the 
ETSP (Lam and Kuypers, 2011). Ammonium $\left(\mathrm{NH}_{4}{ }^{+}\right)$was present between 5-65 m depth, reaching a maximum of $1.96 \mu \mathrm{mol} / \mathrm{kg}$ water at $24 \mathrm{~m}$. Likely sources of $\mathrm{NH}_{4}{ }^{+}$include the dissimilatory nitrate reduction to ammonium (DNRA) and the remineralization of organic matter. With depth, $\mathrm{NH}_{4}{ }^{+}$reached very low values $(0.02 \mu \mathrm{mol} / \mathrm{kg}$ water; $>65 \mathrm{~m})$. It is likely that $\mathrm{NH}_{4}{ }^{+}$is being produced, but consumed by active anammox processes in the upper OMZ, as suggested by Thamdrup et al. (2012). Nitrite $\left(\mathrm{NO}_{2}{ }^{-}\right)$was present in low concentrations ( $\sim 0.5 \mu \mathrm{mol} / \mathrm{kg}$ water) in the surface ocean and through the chemocline, and is attributed to nitrate reduction. Further into the $\mathrm{OMZ}$ core $(65-300 \mathrm{~m}), \mathrm{NO}_{2}{ }^{-}$concentrations increased to a maximum of $7.28 \mu \mathrm{mol} / \mathrm{kg}$ water at $120 \mathrm{~m}$ depth. It has been proposed that this maximum is largely the result of shelf production and horizontal advection (Lam et al., 2009). In general, these trends agree with previous studies in the ETSP including those reported for the MOOMZ-2 cruise (Canfield et al., 2010).

\subsection{BHPs distribution and abundance}

\subsubsection{Water Column}

The total BHP concentration was low in the surface waters $(10 \mathrm{~m} ; 0.06-3.09 \mathrm{ng} / \mathrm{L})$ and generally increased with depth through the upper oxycline, while a maximum occurred between 65 and $240 \mathrm{~m}$ (4.79-23.99 ng/L; Figure 4). The large range of BHP concentrations in the area of maximum abundance may be related to the dynamic nature of these systems (e.g., Ulloa et al., 2012), or to the limited sampling resolution of our study (Table 1). BHP concentrations decreased below the OMZ core, suggesting a decline of microbial biomass. We note that the vertical structure of BHPs reflects the distribution of active bacterial populations, and thus bacterial biomass that exist through the biogeochemical gradients present in the OMZ of the Humboldt Current System (Stevens and Ulloa, 2008; Galán et al., 2009; Canfield et al., 2010; Stewart et al., 2012; Ulloa et al., 2012). In general, the range of BHP concentrations agree with previous studies of the ETSP OMZ (Sáenz et al., 2011) and the Black Sea (Wakeham et al., 2007). 
Three BHPs were identified in water column samples (Figure 4). Bacteriohopanetetrol (BHT) and its putative isomer (BHT II) were the most abundant compounds identified. BHpentol, produced broadly by cyanobacteria (e.g. Talbot et al., 2008; Sáenz et al., 2012), was detected exclusively in the MOOMZ-2 profile, though in relatively low concentrations $(0.003-0.097$ $\mathrm{ng} / \mathrm{L}$ ). The detection of BHpentol in only one study area is likely due to the high volumes of seawater that were filtered at this site (781-2133 L during MOOMZ-2) compared to the more modest volume (40-240 L) filtered in all other profiles (Table 1). For this reason, and since BHpentol has been identified in other OMZ systems (Sáenz et al., 2011), it is likely that BHpentol is present as a minor compound in other areas of the Chilean OMZ here studied. Indeed, we cannot rule the presence of other BHPs in this region, though they are likely below detection limit in our samples. For instance, in addition to BHT, BHT II, and BHpentol, Sáenz et al., (2011) also identified (in order of decreasing abundance) aminotriol, lactoneBHP, and anhydroBHT as minor components of the total BHP pool. However, we note that since this study is primarily concerned with the distribution and abundance of BHT and BHT II, the detection limit for other BHPs has no impact on the scope of our work.

BHT is ubiquitous as a bacterial membrane lipid in marine water column samples, and not surprisingly, was identified in all samples described here. BHT concentrations were low $(<3$ $\mathrm{ng} / \mathrm{L})$ in surface waters $(10 \mathrm{~m})$, reached maximum values $(3.39-10.26 \mathrm{ng} / \mathrm{L})$ in the $\mathrm{OMZ}$ core (65-240 m), and decreased to lowest values (0.06-0.59 $\mathrm{ng} / \mathrm{L})$ with depth (>280 m; Figure 4). Generally, BHT concentrations paralleled trends in microbial cell abundance characteristic of this OMZ system (Stevens and Ulloa, 2008; Canfield et al., 2010; Stewart et al., 2012; Ulloa et al., 2012).

The distribution of BHT II in all of samples exhibited a strong relationship with suboxic to anoxic conditions (Figure 4) and the presence of anammox bacteria reported in previous studies (Galán et al., 2009; Canfield et al., 2010; Stewart et al., 2012; Ulloa et al., 2012). BHT 
II was absent in all surface water samples $(10 \mathrm{~m})$ where oxygen levels were high (215-284 $\mu \mathrm{mol} \mathrm{O}_{2} / \mathrm{kg}$ water; Figure 4) and where anammox bacteria are typically absent (Ganesh et al., 2014). The concentration of BHT II reached a maximum (1.78-13.72 $\mathrm{ng} / \mathrm{L})$ within the upper and core OMZ around 70-240 $\mathrm{m}(0.9-8.3 \mu \mathrm{mol} / \mathrm{kg}$ water $)$, consistent with previous reports off Iquique $\left(\sim 20^{\circ} \mathrm{S}\right)$ indicating a maximum in anammox bacteria abundance at $\sim 50 \mathrm{~m}$ (Galán et al., 2009) and $200 \mathrm{~m}$ (Ulloa et al., 2012). The latter is also consistent with elevated rates of anammox in this part of the OMZ throughout the eastern South Pacific (Dalsgaar et al., 2012). BHT II decreased in abundance with depth below the OMZ core (Figure 4), consistent with previous reports indicating a decline in the abundance of anammox bacteria (Galán et al., 2009; Ulloa et al., 2012).

While the concentration of BHT II indicates the absolute abundance of anammox bacteria in seawater, the BHT II ratio (expressed as BHT II/total BHT) indicates the relative contribution of anammox bacteria with respect to the total bacterial community. Since BHT is a ubiquitous and generic bacterial marker, and the most abundant BHP in marine settings including OMZ systems such as the Chilean OMZ, it can be used to normalize BHT II and to determine its relative abundance. The BHT II ratio was zero at the sea surface due to the absolute absence of BHT II. The ratio increased along the chemocline $(>50 \mathrm{~m})$ where BHT II was first detected, then peaked at 50-240 $\mathrm{m}(0.45-0.57)$, and decreased only slightly with depth around 600-1900 m (0.34-0.56). Notably, BHT II exceeded BHT at $\sim 200 \mathrm{~m}$ in three out of five profiles (Figure 4). To the best of our knowledge, this is the first report of BHT II substantially exceeding BHT (Figure 5). Such elevated contribution of BHT II with respect to BHT likely reflects an enhanced activity of anammox bacteria in this region compared to others OMZ systems, and the preferential production of BHT II over BHT by at least one known marine anammox bacterium Candidatus Scalindua profunda (Rush et al., 2014). Figure 5 shows the relationship between the BHT II ratio and dissolved oxygen concentration in the Chilean OMZ, in comparison to the OMZ systems of Perú, Cariaco Basin, and the Arabian Sea (Sáenz et al., 2011). The highest values were detected in water masses with $<3$ 
$\mu \mathrm{mol} \mathrm{O}_{2} / \mathrm{kg}$ water. Samples from oxygenated waters below the $\mathrm{OMZ}$ were excluded from this relationship as their elevated BHT II ratio values likely reflect the signal of organic matter exported from within the OMZ region, and they possibly do not reflect active, free-living bacteria. The declining BHT and BHT II concentrations with depth (Figure 4) are likely the result of a decreasing standing stock of bacteria with depth as well as the enhanced remineralization of sinking particles during transfer through the water column.

\subsubsection{Particle export}

Size fractionated samples $(0.3-3.0 \mu \mathrm{m}$ and $>3.0 \mu \mathrm{m})$ collected during the MOOMZ-2 cruise off Iquique $\left(20.1^{\circ} \mathrm{S}\right)$ allow us to investigate the distribution of BHPs in fractions that are considered to primarily represent free-living microorganisms and small aggregates $(0.3-3.0$ $\mu \mathrm{m})$, and particle-associated microorganisms and larger aggregates $(>3.0 \mu \mathrm{m}$; e.g. Rieck et al., 2015). Thus, size-fractioned particle analysis allows for further query of the source and transport of BHT and BHT II in this system. We note that the summed concentration profiles of BHPs in the $0.3-3.0 \mu \mathrm{m}$ and $>3.0 \mu \mathrm{m}$ size fractions (this is the $>0.3 \mu \mathrm{m}$ size fraction) are similar to BHP concentrations measured in those samples collected using $0.7 \mu \mathrm{m}$ filters (Figures 4 and 6), and to other studies in OMZ systems (Wakeham et al., 2007; Sáenz et al., 2011). BHT was the only compound detected at well-oxygenated surface waters $(<0.1 \mathrm{ng} / \mathrm{L}$; $10 \mathrm{~m})$. Both BHT and BHT II were present at depth $(>25 \mathrm{~m})$ in the $0.3-3.0 \mu \mathrm{m}$ and $>3.0 \mu \mathrm{m}$ size fractions. The presence of BHT and BHT II in both size fractions, suggesting that these compounds are produced by both free-living and particle-associated microorganisms, and/or by free-living microorganisms that form large aggregates $(>3.0 \mu \mathrm{m})$.

The concentration of BHT II in the free-living fraction reached a maximum concentration of 1.65-1.09 $\mathrm{ng} / \mathrm{L}$ at $70-200 \mathrm{~m}$ within the $\mathrm{OMZ}$ core $\left(<3 \mu \mathrm{mol} \mathrm{O}_{2} / \mathrm{kg}\right.$ water $)$. This maximum value is in agreement with metagenomic studies that identified high relative abundance of anammox sequences between 70-200 $\mathrm{m}$ in free-living size fractions (Ganesh et al., 2014). However, we found that the $>3.0 \mu \mathrm{m}$ size fraction typically provides higher concentrations of 
BHT and BHT II at any depth compared to the $0.3-3.0 \mu \mathrm{m}$ size fraction (Figure 6). The latter likely reflects the tendency of free-living microorganisms and small particles to aggregate into larger particles (Alldredge and Silver, 1988). Since the BHT II ratio is more elevated in the $>3 \mu \mathrm{m}$ size fraction than the $0.3-3.0 \mu \mathrm{m}$ size fraction at any particular depth, it is likely that BHT II is actively produced, and at elevated rates compared to BHT, in the particleassociated size fraction. This result contradicts those observations from the coding sequences of anammox planctomycetes (Ganesh et al., 2014) and anammox-associated transcripts (Ganesh et al., 2015) in the Chilean OMZ, which were enriched up to 3- and 15-fold, respectively, in free-living fractions $(0.2-1.6 \mu \mathrm{m})$ as compared to larger size fractions $(>1.6$ $\mu \mathrm{m})$. However, these molecular studies cannot quantify cellular abundance in either size fraction, or how changes in particle load relate to changes in the abundance of the sizefractioned communities. We only detected larger BHP concentrations in the $0.3-3.0 \mu \mathrm{m}$ size fraction than the $>3.0 \mu \mathrm{m}$ size fraction at $200 \mathrm{~m}$ depth in the core of the OMZ, which is consistent with a larger standing stock, activity and diversity of bacteria, and thus BHPs production, in these waters (Galán et al., 2009; Lam et al., 2009; Ulloa et al., 2012). Our data suggests that both free-living and particle-associated bacteria are producing BHT and BHT II, and that free-living fractions are likely forming larger aggregates $(>3.0 \mu \mathrm{m})$. Additionally, while the BHT II ratio in the small size fraction is variable from $50-600 \mathrm{~m}$, likely due to bacterial heterogeneity and intensive reworking of small particles, it is relatively stable and more elevated in the large size fraction. The fact that the BHT II in the $>3.0 \mu \mathrm{m}$ size remains $>0.5$ with depth suggests that a fraction of the BHT II produced in the OMZ core is transported to depth via sinking particles. In the section below we describe how this signal is transferred to surface sediments.

\subsubsection{Surface sediments}

Seven BHP structures were identified in surface sediment samples from a total of seven localities between 23 and $27^{\circ} \mathrm{S}$. In decreasing order of abundance, these structures include BHT, BHT II, 2-methylbacteriohopanetetrol (2-MeBHT), bacteriohopanepentol (BHpentol), 
aminobacteriohopanetriol (aminotriol), adenosylhopane, and anhydrobacteriohopanetetrol (anhydroBHT; Figure 7). The larger diversity of BHPs in surface sediments as compared to the overlying water column is likely due to the integrated deposition and accumulation of POM from the water column over time. For example, total BHP concentrations in surface sediments ranged from 0.55 to $3.29 \mathrm{mg} / \mathrm{g}$ compared to $19.19 \mathrm{ng} / \mathrm{L}$, as measured in the most concentrated water column sample (BiG RAPA; $240 \mathrm{~m}$ ). Additionally, it is possible that in situ microbial activity may contribute to the BHP signature in surface sediments.

As in the overlying water column, BHT and BHT II were the most abundant BHPs in surface sediments, accounting for $30-42 \%$ and $51-66 \%$ of total BHP, respectively. In combination, BHT and BHT II accounted for $>95 \%$ of the total BHP pool. BHT II concentrations exceeded those of BHT in all samples, while BHT II ratio values $(0.55-0.69)$ greatly exceeded those reported in surface sediments off Perú (0.22-0.29; Sáenz et al., 2011). Our BHT II ratio values are comparable with those measured within the $\mathrm{OMZ}$ core in the overlying water column (0.46-0.64), suggesting that the BHT II signal from the OMZ off the coast of northern Chile is transferred to, and preserved in, surface sediments. However, since anammox is a common bacterial metabolism in anoxic marine sediments, and a likely additional source of BHT II in this environment, we cannot rule out in situ production in surface sediments.

Minor BHPs accounted for 3.2-6.1\% of the total BHP at each locality. 2-MeBHT (1.8-2.7\%), BHpentol (0.6-1.1\%), and aminotriol (0.7-1.7\%) were identified in all samples, while adenosylhopane (0.6 and $2.2 \%)$ and anhydroBHT (0.6 and $0.8 \%)$ were limited to two samples each. Adenosylhopane is often associated with soil bacteria and consequently used as a marker for terrestrial input (Talbot and Farrimond, 2007; Cooke et al., 2008). Thus, while the presence of adenosylhopane in two samples suggests the influence of terrestrial input, its absence from the other five sites suggests a lack of it. Also, anhydroBHT was identified in sediments that contained the highest concentration of total BHP (1.1-3.3 $\mu \mathrm{g} / \mathrm{g})$. AnhydroBHT is a diagenetic degradation product of BHT and composite BHPs under acidic and marine 
sedimentary conditions (Bednarczyk et al., 2005; Schaeffer et al., 2008, 2010). Finally, 2 MeBHT was present in all surface sediments (10.6-78.6 ng/g). The abundance of this compound is particularly interesting because $2-\mathrm{MeBHT}$ has been interpreted as a biomarker for cyanobacteria (e.g. Summons et al., 1999). However, 2-methylhopanoids are now known to be produced by other bacteria, particularly within the alphaproteobacteria (e.g. Rashby et al., 2007; Welander et al., 2010; Ricci et al., 2014; Newman et al., 2016), and are rarely observed in the marine environment. Despite this, 2-MeBHT did not coincide with adenosylhopane in surface sediments, so it is likely that it was produced locally and does not represent a transported signal from the terrestrial environment. Notably, no apparent correlation was found between any BHP and latitude, water depth, or distance from the coast.

\subsubsection{Deeply buried sediments}

Long-term changes in anammox activity may be studied in the geological record using the BHT II ratio, which provides an opportunity to characterize the intensity, spatial and temporal scales of anammox activity and, by extension, OMZ change. BHT and BHT II were identified throughout deeply buried sediments from core GeoB15016 corresponding to the Glacial Termination II leading to the Eemian interglacial period (Marine Isotope Stages 6 to 5 between 150 and $125 \mathrm{ky} \mathrm{BP;} \mathrm{Martínez-Méndez} \mathrm{et} \mathrm{al.,} \mathrm{2013).} \mathrm{The} \mathrm{BHT} \mathrm{II} \mathrm{ratio} \mathrm{increased}$ during Termination II to values of $>0.8$ during the interglacial period, possibly reflecting a decrease in oxygenation and enhanced anammox abundance accompanying the transition to the warmer-than-present climate of the Eemian (Figure 8). Notably, the $\delta^{15} \mathrm{~N}$ of bulk sediment, a proxy commonly used to trace the intensity of bacterial denitrification in overlying waters (e.g., Altabet et al., 1995; Ganeshram et al., 1995; Galbraith et al., 2013), showed a marked enrichment during Termination II that paralleled the increase in the BHT II ratio. This result indicates that both bacterial denitrification and anammox were enhanced during Termination II and deglacial times, consistent with the proposed overall decrease in dissolved oxygen of the gloabl ocean (Jaccard and Galbraith, 2012), and with changes in the global $\mathrm{N}$ inventory due to enhanced denitrification (Altabet et al., 1995; Ganeshram et al., 
1995; Galbraith et al., 2013). Our finding confirms that BHT II is well preserved in deeply buried sediments over hundreds of thousands of years, allowing for the reconstruction of anammox during time periods of warm transitions leading to the expansion of marine oxygendepleted waters.

\section{Conclusions}

We report on the distribution of BHPs in suspended organic matter across the OMZ of the Humboldt Current System off northern Chile between $20.1^{\circ} \mathrm{S}$ and $30.2^{\circ} \mathrm{S}$, as well as in surface and deeply buried marine sediments (125-150 ky). BHT and BHT II were the most abundant compounds in water column samples, particularly where OMZ waters were most persistent, and where intrusions of oxygenated water were less common. Water column samples were characterized by a low diversity of BHPs that also included a minor contribution of BHpentol. The BHT II ratio (expressed as BHT II/total BHT) increased as oxygen content decreased in the water column, consistent with previous results from Perú, the Cariaco Basin and the Arabian Sea, and in line with microbiological evidence which indicates intense anammox activity in OMZ waters of this region. The diversity of BHPs in surface sediments was greater than water column samples and comprised 7 compounds. We highlight that the signature of the BHT II signature was transported from the water column to surface sediments, and preserved in older sediments, where the BHT II ratio correlates with $\delta^{15} \mathrm{~N}$ values of bulk sediment during the glacial-interglacial transition. This study confirms that the production, transport, and preservation of BHT II in oxygen-deficient marine settings offers a proxy for past changes in the relative importance of anammox, and fluctuations in nitrogen cycling in response to ocean redox changes through the geological record.

\section{Acknowledgments}

We are thankful to the captains, crews and scientists of the German R/V Sonne cruise SO-211 (ChiMeBo), the Chilean R/V Vidal Gormaz cruise MOOMZ-2, and the US R/V Melville cruise BiG RAPA. We particularly thank the chief scientists D. Hebbeln, O. Ulloa and D. 
Repeta, respectively. We also wish to thank L. Nuñez, J. Vera, B. Srain, R. Castro, A. Ávila, M. Mohtadi, R. De Pol-Holz, G. Martínez-Méndez, G. Alarcón, S. Lincoln, F. Stewart, and C. Colonero for sample collection and/or laboratory assistance. The ChiMeBo project was funded by the Bundesministerium für Bildung \& Forschung (BMBF), the MOOMZ-2 cruise was funded by the Agouron Institute, and the BiG RAPA cruise was funded by the Center for Microbial Oceanography: Research and Education (C-MORE). Research at MIT was supported by the NASA Astrobiology Institute. J. Sepúlveda and R. Summons also thank the MIT-Chile MISTI Global Seed Funds grant program for funding. S. Pantoja and C. Lange thank the COPAS Sur-Austral CONICYT PIA PFB31 for partial funding. M. Caniupán thanks the CONICYT/PAI "Concurso Nacional Apoyo al Retorno de Investigadores desde el Extranjero, Convocatoria 2013” (Grant 821320066) for funding. 


\section{References}

Alldredge, A.L., Silver, M.W. (1988). Characteristics, dynamics and significance of marine snow. Progress in Oceanography, 20, 41-82.

Altabet, M.A., Francois, R., Murray, D.W., Prell, W.L. (1995). Climate-related variations in denitrification in the Arabian Sea from sediment ${ }^{15} \mathrm{~N} /{ }^{14} \mathrm{~N}$ ratios. Nature, 373, 506-509.

Armstrong, R.A., Lee, C., Hedges, J.I., Honjo, S., Wakeham, S.G. (2002). A new, mechanistic model for organic carbon fluxes in the ocean based on the quantitative association of POC with ballast minerals. Deep-Sea Research II, 49, 219-236.

Bednarczyk, A., Hernandez, T.C., Schaeffer, P., Adam, P., Talbot, H.M., Farrimond, P., Riboulleau, A., Largeau, C., Derenne, S., Rohmer, M., Albrecht, P. (2005). 32,35Anhydrobacteriohopanetetrol: an unusual bacteriohopanepolyol widespread in recent and past environments. Organic Geochemistry, 36, 673-677.

Berndmeyer, C., Thiel, V., Schmale, O., Wasmund, N., Blumenberg, M. (2014). Biomarkers in the stratified water column of the Landsort Deep (Baltic Sea). Biogeosciences, 11, 70097023. 
Bettencourt, J.H., López, C., Hernández-García, E., Montes, I., Sudre, J., Dewitte, B., Paulmier, A., Garçon, V. (2015). Boundaries of the Peruvian oxygen minimum zone shaped by coherent meoscale dynamics. Nature Geoscience Letters, 8, 937-941.

Bligh, E.G., Dyer, W.J., (1959). A rapid method of total lipid extraction and purification. Canadian Journal of Biochemistry and Physiology, 37, 911-917.

Blumenberg, M., Kruger, M., Nauhaus, K., Talbot, H.M., Oppermann, B.I., Seifert, R., Pape, T., Michaelis, W. (2006). Biosynthesis of hopanoids by sulfate-reducing bacteria (genus Desulfovibrio). Environmental Microbiology, 8, 1220-1227.

Blumenberg, M., Seifert, R., Michaelis, W. (2007). Aerobic methanotrophy in the oxicanoxic transition zone of the Black Sea water column. Organic Geochemistry, 38, 84-91.

Blumenberg, M., Berndmeyer, C., Moros, M., Muschalla, M., Schmale, O., Thiel, V. (2013). Bacteriohopanepolyols record stratification, nitrogen fixation and other biogeochemical perturbations in Holocene sediments of the central Baltic Sea. Biogeosciences, 10, 27252735.

Bograd, S.J., Castro, C.G., Di Lorenzo, E., Palacios, D.M., Bailey, H., Gilly, W., Chavez, F.P. (2008). Oxygen declines and the shoaling of the hypoxic boundary in the California Current. Geophysical Research Letters, 35, L12607.

Brocks, J.J., Summons, R.E. (2003). Biomarkers of Early Life. Biogeochemistry, 8, 63-115.

Canfield, D. E., Stewart, F. J., Thamdrup, B., De Brabandere, L., Dalsgaard, T., DeLong, E. F., et al. (2010). A Cryptic Sulfur Cycle in Oxygen-Minimum-Zone Waters off the Chilean Coast. Science, 330, 1375-1378. 
Capone, D. G., Hutchins, D. A. (2013). Microbial biogeochemistry of coastal upwelling regimes in a changing ocean. Nature Geosciences, 6, 711-717.

Chavez, F., Messie, M. (2009). A comparison of eastern boundary upwelling ecosystems. Progress in Oceanography, 83, 80-96.

Cooke, M.P., Talbot, H.M., Farrimond, P. (2008). Bacterial populations recorded in bacteriohopanepolyol distributions in soils from Northern England. Organic Geochemistry, $39,1347-1358$

Dalsgaard, T., Thamdrup, B., Farías, L., Revsbech, N.P. (2012). Anammox and denitrification in the oxygen minimum zone of the eastern South Pacific. Limnology and Oceanography, 57, $1331-1346$.

Daneri, G., Dellarossa, V., Quiñones, R., Jacob, B., Montero, P., Ulloa, O. (2000). Primary production and community respiration in the Humboldt Current System off Chile and associated oceanic areas. Marine Ecology Progress Series, 197, 41-49.

Doughty, D.M., Hunter, R.C., Summons, R.E., Newman, D.K. (2009). 2-Methylhopanoids are maximally produced in akinetes of Nostoc punctiforme: geobiological implications. Geobiology, 7, 524-532.

Eickhoff, M., Talbot, H.M., Peckmann, J., Kappler, A. (2013). Oxidation of Fe(II) leads to increased $\mathrm{C}-2$ methylation of pentacyclic triterpenoids in the anoxygenic phototrophic bacterium Rhodopseudomonas palustris strain TIE-1. Geobiology, 11, 268-278. 
Farías, L., Paulmier, A., Gallegos, M. (2007). Nitrous oxide and N-nutrient cycling in the oxygen minimum zone off northern Chile. Deep-Sea Research I, 54, 164-180.

Farrimond, P., Fox, P.A., Innes, H.E., Miskin, I.P., Head, I.M. (1998). Bacterial sources of hopanoids in recent sediments: improving our understanding of ancient hopane biomarkers. Ancient Biomolecules, 2, 147-166.

Fischer, W.W., Summons, R.E., Pearson, A. (2005). Targeted genomic detection of biosynthetic pathways: anaerobic production of hopanoid biomarkers by a common sedimentary microbe. Geobiology, 3, 33-40.

Fuenzalida, R., Schneider, W., Garces-Vargas, J., Bravo, L., Lange, C. (2009). Vertical and horizontal extension of the oxygen minimum zone in the Eastern South Pacific Ocean. DeepSea Research II, 56, 1027-1038.

Galán, A., Molina, V., Thamdrup, B., Woebken, D., Lavik, G., Kuypers, M.M.M., Ulloa, O. (2009). Anammox bacteria and anaerobic oxidation of ammonium in the oxygen minimum zone off northern Chile. Deep-Sea Research II, 56, 1021-1031.

Ganesh, S., Parris, D.J., DeLong, E.F., Stewart, F.J. (2014). Metagenomic analysis of sizefractioned picoplankton in marine oxygen minimum zone. The ISME Journal, 8, 187-211.

Ganesh, S., Bristow, L.A., Larsen, M., Sarode, N., Thamdrup, B, Stewart, F. (2015). Sizefraction partitioning of community gene transcription and nitrogen metabolism in a marine oxygen minimum zone. The ISME Journal, 9, 2682-2696.

Galbraith, E.D., Kienast, M., et al. (2013). The acceleration of ocean denitrification during deglacial warming. Nature Geoscience Articles, 6, 579-584. 
Ganeshram, R.S., Pedersen, T.F., Calvert, S.E., Murray, J.W. (1995). Large changes in oceanic nutrient inventories from glacial to interglacial periods. Nature, 376, 755-758.

Hartner, T., Straub, K.L., Kannenberg, E. (2005). Occurrence of hopanoid lipids in anaerobic Geobacter species. FEMS Microbiology Letters, 243, 59-64.

Hebbeln, D. and cruise participants (2011). Report and preliminary results of R/V Sonne cruise SO211, Valparaiso-Valparaiso, 2 November - 29 November, 2010, ChiMeBo, Berichte aus dem Fachbereich Geowissenschaften der Universität Bremen ; 279

Hedges, J.I., Baldock, J.A., Géllinas, Y., Lee, C., Peterson, M., Wakeham, S.G. (2001). Evidence for non-selective preservation of organic matter in sinking marine particles. Letters to Nature, $409,801-804$.

Jaccard, S.L., Galbraith, E.D. (2012). Large climate-driven changes of oceanic oxygen concentrations during the last deglaciation. Nature Geoscience, 5, 151-156.

Jaeschke, A., Lewan, M.D., Hopmans, E.C., Schouten, S., Sinninghe Damsté, J.S. (2008). Thermal stability of ladderane lipids as determined by hydrous pyrolysis. Organic Geochemistry, 39, 1735-1741.

Jaeschke, A., Ziegler, M., Hopmans, E.C., Reichart, G.J., Lourens, L.J., Schouten, S., Sinninghe Damsté, J.S. (2009). Molecular fossil evidence for anaerobic ammonium oxidation in the Arabian Sea over the last glacial cycle. Paleoceanography, 24, PA2202.

Karl, D.M., Knauer, G.A., Martin, J.H. (1988). Downward flux of particulate organic matter in the ocean: A particle decomposition paradox. Nature, 332, 438-441. 
Keeling, R. F., Kortzinger, A., Gruber, N. (2010). Ocean deoxygenation in a warming world. Annual Reviews in Marine Science, 2, 199-229.

Kharbush, J.J., Ugalde, J.A., Hogle, S.L., Allen, E.E., Aluwiharea, L.I. (2013). Composite bacterial hopanoids and their microbial producers across oxygen gradients in the water column of the California Current. Applied and Environmental Microbiology, 79, 7491-7501.

Kuypers, M.M.M., Sliekers, A.O., Lavik, G., Schmid, M., Jorgensen, B.B., Kuenen, J.G., Sinninghe Damsté, J.S., Strous, M., Jetten, M.S.M. (2003). Anaerobic ammonium oxidation by anammox bacteria in the Black Sea. Nature, 422, 608-611.

Lam, P., Kuypers, M. M. M. (2011). Microbial Nitrogen Cycling Processes in Oxygen Minimum Zones. Annual Review of Marine Science, 3, 317-345.

Lam, P., Lavik, G., Jensen, M. M., van de Vossenberg, J., Schmid, M., Woebken, D., et al., (2009). Revising the nitrogen cycle in the Peruvian oxygen minimum zone. Proceedings of the National Academy of Sciences, 106, 4752-4757.

Lisiecki, L.E., Raymo, M.E. (2005). A Pliocene-Pleistocene stack of 57 globally distributed benthic $\delta^{18} \mathrm{O}$ records. Paleoceanography, 20, PA1003.

Martínez-Méndez, G., Hebbeln, D., Mohtadi, M., Lamy, F., De Pol-Holz, R., Reyes-Macaya, D., Freudenthal, T. (2013). Changes in the advection of Antarctic Intermediate Water to the northern Chilean coast during the last 970 kyr. Paleooceanography, 28, 607-618.

Montecino, V., Lange, C.B. (2009). The Humboldt Current System: Ecosystem components and processes, fisheries, and sediment studies. Progress in Oceanography, 83, 65-79. 
Newman, D.K., Neubauer, C., Ricci, J., Wu, C-H., Pearson, A. (2016). Cellular and molecular biological approaches to interpreting ancient biomarkers. Annual Reviews Earth Planetary Sciences, 44, 493-522.

Nishihara, M., Koga, Y. (1987). Extraction and composition of polar lipids from the archaebacterium, Methanobacterium thermoautotrophicum: effective extraction of tetraether lipids by an acidified solvent. Journal of Biochemistry, 101, 997-1005.

Ourisson, G., Albrecht, P., Rohmer, M. (1979). Hopanoids: palaeochemistry and biochemistry of a group of natural products. Pure and Applied Chemistry, 51, 709-729.

Paulmier, A., Ruiz-Pino, D., Garçon, V., Farías, L. (2006). Maintaining of the East South Pacific Oxygen Minimum Zone (OMZ) off Chile. Geophysical Research Letters, 33, L20601.

Paulmier, A., Ruiz-Pino, D. (2009). Oxygen minimum zones (OMZs) in the modern ocean. Progress in Oceanography 80, 113-128.

Pearson, A., Flood Page, S.R., Jorgenson, T.L., Fischer, W.W., Higgins, M.B. (2007). Novel hopanoid cyclases from the environment. Environmental Microbiology, 9, 2175-2188.

Pearson, A., Leavitt, W.D., Sáenz, J.P., Summons, R.E., Tam, M.C.-M., Close, H.G. (2009). Diversity of hopanoids and squalene-hopene cyclases across a tropical land-sea gradient. Environmental Micorbiology, 11, 1208-1223.

Rashby, S.E., Sessions, A.L., Summons, R.E., Newman, D.K. (2007). Biosynthesis of 2methylbacteriohopanepolyols by an anoxygenic phototroph. Proceedings of the National Academy of Science U.S.A. 104, 15099-15104. 
Rattray, J.E., van de Vossenberg, J., Hopmans, E.C., Kartal, B., van Niftrik, L., Rijpstra, W.I.C., Strous, M., Jetten, M.S.M., Schouten, S., Sinninghe Damsté, J.S. (2008). Ladderane lipid distribution in four genera of anammox bacteria. Archives of Microbiology, 190, 51-66.

Ricci, J.N., Coleman, M.L., Welander, P.V., Sessions, A.L., Summons, R.E., Spear, J.R., Newman, D.K. (2014). Diverse capacity for 2-methylhopanoid production correlates with a specific ecological niche. The ISME Journal, 8, 675-684.

Rieck, A., Herlemann, D.P.R., Jürgens, K., Grossart, H.-P. (2015). Particle-Associated Differ from Free-Living Bacteria in Surface Waters of the Baltic Sea. Frontiers in Microbiology, 6, 1297.

Rohmer, M., Bouvier-Nave, P., Ourisson, G. (1984). Distribution of hopanoid triterpenes in prokaryotes. Journal of General Microbiology, 130, 1137-1150.

Rush, D., Jaeschke, A., Geenevasen, J.A., Tegelaar, E., Pureveen, J., Lewan, M.D., Schouten, S., Sinninghe Damsté, J.S. (2014). Generation of unusual branched long chain alkanes from hydrous pyrolysis of anammox bacterial biomass. Organic Geochemistry, 76, 136-145.

Rush, D., Sinninghe Damsté, J.S., Poulton, S.W., Thamdrup, B., Garside, A.L., González, J. A., Schouten, S., Jetten, M.S.M., Talbot, H.M. (2014). Anaerobic ammonium-oxidising bacteria: A biological source of the bacteriohopanetetrol stereoisomer in marine sediments. Geochimica Et Cosmochimica Acta, 140, 50-64.

Rush, D., Sinninghe Damsté, J.S., Hopmans, E.C., Talbot, H.M. Bacteriohopanepolyols in Mediterranean sapropel events: indications for tracing ancient anammox [abstract]. In: British Organic Geochemistry Society Meeting; 2015 July 2-3; Glasgow, Scotland. Abstract P5. 
Sáenz, J.P. (2010). Exploring the Distribution and Physiological Roles of Bacterial Membrane Lipids in the Marine Environment (Doctoral dissertation).

Sáenz, J.P., Wakeham, S.G., Eglinton, T.I., Summons, R.E. (2011). New constraints on the provenance of hopanoids in the marine geologic record: Bacteriohopanepolyols in marine suboxic and anoxic environments. Organic Geochemistry, 42, 1351-1362.

Sáenz, J.P., Sezgin, E., Schwille, P., Simons, K. (2012). Functional convergence of hopanoids and sterols in membrane ordering. Proceedings of the National Academy of Sciences, 109, $14236-14240$.

Sáenz, J.P., Grosser, D., Bradley, A.S., Lagny, T.J., Lavrynenko, O., Broda, M., Simons, K. (2015). Hopanoids as functional analogues of cholesterol in bacterial membranes. Proceedings of the National Academy of Sciences, 112, 11971-11976.

Schaeffer, P., Schmitt, G., Adam, P., Rohmer, M. (2008). Acid-catalyzed formation of 32,35anhydrobacteriohopanetetrol from bacteriohopanetetrol. Organic Geochemistry, 39, 14791482.

Schaeffer, P., Schmitt, G., Adam, P., Rohmer, M. (2010). Abiotic formation of 32,35anhydrobacteriohopanetetrol: a geomimetic approach. Organic Geochemistry, 41, 1005-1008.

Sinninghe Damsté, J.S., Strous, M., Rijpstra, W.I.C, Hopmans, E., Geenevasen, J.A.J, van Duin, A.C.T., van Niftrik, L.A., Jetten, M.S.M. (2002). Linearly concatenated cyclobutane lipids form a dense bacterial membrane. Nature, 419, 708-712. 
Sinninghe Damsté, J.S, Rijpstra, W.I.C., Schouten, S., Fuerst, J.A., Jetten, M.S.M., Strous, M. (2004). The occurrence of hopanoids in planctomycetes: implications for the sedimentary biomarker record. Organic Geochemistry, 35, 561-566.

Smethie, W.M. (1987). Nutrient regeneration and denitrification in low oxygen fjords. DeepSea Research, 34, 983-1006.

Stevens, H., Ulloa, O. (2008). Bacterial diversity in the oxygen minimum zone of the eastern tropical South Pacific. Environmental Microbiology, 10, 1244-1259.

Stewart, F.J., Ulloa, S., DeLong, E.F. (2012). Microbial metatranscriptomics in a permanent marine oxygen minimum zone. Environmental Microbiology, 14, 23-40.

Stramma, L., Johnson, G.C., Sprintall, J., Mohrholz, V. (2008). Expanding oxygen-minimum zones in the tropical oceans. Science, 320, 655-658.

Sturt, H.F., Summons, R.E., Smith, K., Elvert, M., Hinrichs, K.-U. (2004). Intact polar membrane lipids in prokaryotes and sediments deciphered by high-performance liquid chromatography/electrospray ionization multistage mass spectrometry-new biomarkers for biogeochemistry and microbial ecology. Rapid Communications in Mass Spectrometry, 18, $617-628$.

Summons, R.E., Lincoln, S.A. (2012). Biomarkers: Informative molecules for studies in geobiology. In: Knoll, A.H., Canfield, D.E., and Konhauser, K.O. (Eds.), Fundamentals of Geobiology.

Summons R.E., Brassell, S.C., Eglinton, G., Evans, E., Horodyski, R.J., Robinson, N., Ward, D.M. (1988). Distinctive hydrocarbon biomarkers from fossiliferous sediments of the Late 
Proterozoic Walcott Member, Chuar Group, Grand Canyon, Arizona. Geochimica et Cosmochimica Acta, 52, 2625-2637.

Summons, R.E., Jahnke, L.L., Hope, J.M., Logan, G.A. (1999). 2-Methylhopanoids as biomarkers for cyanobacterial oxygenic photosynthesis. Nature, 400, 554-557.

Talbot, H.M., Squier, A.H., Keely, B.J., Farrimond, P. (2003). Atmospheric pressure chemical ionisation reversed-phase liquid chromatography/ion trap mass spectrometry of intact bacteriohopanepolyols. Rapid Communications in Mass Spectrometry, 17, 728 -737.

Talbot, H.M., Farrimond, P. (2007). Bacterial populations recorded in diverse sedimentary biohopanoid distributions. Organic Geochemistry, 38, 1212-1225.

Talbot, H.M., Rohmer, M., Farrimond, P. (2007). Rapid structural elucidation of composite bacterial hopanoids by atmospheric pressure chemical ionisation liquid chromatography/ion trap mass spectrometry. Rapid Communications in Mass Spectrometry, 21, 880 - 892.

Thamdrup, B. (2012). New pathways and processes in the global nitrogen cycle. Annual Review of Ecology, Evolution, and Systematics, 43, 407-428.

Ulloa, O., Canfield, D.E., DeLong, E.F., Letelier, R.M., Stewart, F.J. (2012). Microbial oceanography of anoxic oxygen minimum zones. Proceedings of the National Academy of Science, 109, 15996-16003.

Wakeham, S.G., Amann, R., Freeman, K.H., Hopmans, E.C., Jorgensen, B.B., Putnam, I.F., Schouten, S., Sinninghe Damsté, J.S., Talbot, H.M., Woebken, D. (2007). Microbial ecology of the stratified water column of the Black Sea as revealed by a comprehensive biomarker study. Organic Geochemistry, 38, 2070-2097. 
Wakeham, S.G., Turich, C., Schubotz, F., Podlaska, A., Li, X.N.N., Varela, R., Astor, Y., Sáenz, J.P., Rush, D., Sinninghe Damsté, J.S., Summons, R.E., Scranton, M.I., Taylor, G.T., Hinrichs, K.-U. (2012). Biomarkers, chemistry and microbiology show chemoautotrophy in a multilayer chemocline in the Cariaco Basin. Deep-Sea Research I, 63, 133-156.

Welander, P.V., Hunter, R.C., Zhang, L.C., Sessions, A.L., Summons, R.E., Newman, D.K. (2009). Hopanoids play a role in membrane integrity and $\mathrm{pH}$ homeostasis in Rhodopseudomonas palustris TIE-1. Journal of Bacteriology, 191, 6145-6156.

Welander, P.V., Coleman, M.L., Sessions, A.L., Summons, R.E., Newman, D.K. (2010). Identification of a methylase required for 2-methylhopanoid production and implications for the interpretation of sedimentary hopanes. Proceedings of the National Academy of Science U.S.A., 107, 8537-8542.

Welander, P.V., Doughty, D.M., Wu, C.H., Mehay, S., Summons, R.E., Newman, D.K. (2012). Identification and characterization of Rhodopseudomonas palustris TIE-1 hopanoid biosynthesis mutants. Geobiology, 10, 163-177.

Wright, J.J., Konwar, K.M., Hallam, S.J. (2012). Microbial ecology of expanding oxygen minimum zones. Nature Reviews Microbiology, 10, 381-394. 
Tables

\begin{tabular}{|c|c|c|c|c|c|c|c|c|}
\hline Cruise & & Station & $\begin{array}{l}\text { Date Collected } \\
\text { (MM/YY) }\end{array}$ & $\begin{array}{l}\text { Latitude } \\
\left({ }^{\circ} \mathrm{S}\right)\end{array}$ & $\begin{array}{l}\text { Longitude } \\
\left({ }^{\circ} \mathrm{W}\right)\end{array}$ & $\begin{array}{l}\text { Water Depth } \\
\text { (m) }\end{array}$ & $\begin{array}{l}\text { Water Filtered } \\
\text { (L) }\end{array}$ & $\begin{array}{l}\text { Sediment Extracted } \\
(\mathrm{g})\end{array}$ \\
\hline \multicolumn{9}{|l|}{ Water Column } \\
\hline MOOMZ-2 & 08-18/08/2009 & 3 & 08/09 & 20.12 & 70.42 & $10-600$ & $781-2133$ & - \\
\hline BiG RAPA & $18 / 11-14 / 12 / 2010$ & 1 & $11 / 10$ & 20.33 & 70.81 & $0-1900$ & $200-240$ & - \\
\hline ChiMeBo & $02-29 / 11 / 2010$ & 15007 & $11 / 10$ & 25.07 & 70.67 & $10-850$ & $40-100$ & - \\
\hline ChiMeBo & $02-29 / 11 / 2010$ & 15004 & $11 / 10$ & 27.45 & 71.16 & $10-1200$ & $40-100$ & - \\
\hline ChiMeBo & $02-29 / 11 / 2010$ & 15024 & $11 / 10$ & 30.24 & 71.78 & $10-1000$ & $40-100$ & - \\
\hline \multicolumn{9}{|c|}{ Surface Sediments } \\
\hline ChiMeBo & $02-29 / 11 / 2010$ & 15012 & $11 / 10$ & 23.59 & 70.67 & 529 & - & 5 \\
\hline ChiMeBo & $02-29 / 11 / 2010$ & 15011 & $11 / 10$ & 23.85 & 70.65 & 1113 & - & 5 \\
\hline ChiMeBo & $02-29 / 11 / 2010$ & 15007 & $11 / 10$ & 25.07 & 70.66 & 920 & - & 5 \\
\hline ChiMeBo & $02-29 / 11 / 2010$ & 15008 & $11 / 10$ & 25.20 & 70.68 & 539 & - & 5 \\
\hline ChiMeBo & $02-29 / 11 / 2010$ & 15022 & $11 / 10$ & 27.29 & 71.05 & 545 & - & 5 \\
\hline ChiMeBo & $02-29 / 11 / 2010$ & 15004 & $11 / 10$ & 27.45 & 71.16 & 1200 & - & 5 \\
\hline ChiMeBo & $02-29 / 11 / 2010$ & 15005 & $11 / 10$ & 27.50 & 71.13 & 957 & - & 5 \\
\hline \multicolumn{9}{|c|}{ Buried Sediments } \\
\hline ChiMeBo & $02-29 / 11 / 2010$ & 15016 & $11 / 10$ & 27.50 & 71.13 & 971 & - & 2 \\
\hline
\end{tabular}

Table 1. Summary of sampling types and locations during the three independent oceanographic cruises described here. 


\section{Figure Legends}

Figure 1. (A) Map of northern Chile showing the locations of sampling stations where water column, surface sediment, and deeply buried sediment samples were collected. (B) Map of South America showing the study area in the OMZ system off the coast of northern Chile.

Figure 2. Cross sections of physical-chemical parameters from the ETSP OMZ off northern Chile between $\sim 19^{\circ} \mathrm{S}$ and $31^{\circ} \mathrm{S}$ : dissolved oxygen $(\mu \mathrm{mol} / \mathrm{kg})$, temperature $\left({ }^{\circ} \mathrm{C}\right)$, and salinity (PSU) as recorded during the ChiMeBo, MOOMZ-2 and BiG RAPA cruises. Note that the cruise measurements, indicated as grey vertical markers, were obtained at different times.

Figure 3. Representative depth profiles of nutrients $\left(\mathrm{NO}_{2}^{-}, \mathrm{NO}_{3}^{-}\right.$, and $\left.\mathrm{NH}_{4}{ }^{+} ; \mu \mathrm{g} / \mathrm{kg}\right)$ and dissolved oxygen $(\mu \mathrm{mol} / \mathrm{kg})$ from the OMZ off the coast of northern Chile during the BiG RAPA cruise in November $2010\left(20.3^{\circ} \mathrm{S}\right)$.

Figure 4. Depth profiles of dissolved oxygen (A; $\mu \mathrm{mol} / \mathrm{kg}$ ), individual BHPs (B; ng/L), and the BHT II ratio (C; BHT II/total BHT) in samples collected from MOOMZ-2 (20.1 $\left.{ }^{\circ} \mathrm{S}\right), \mathrm{BiG}$

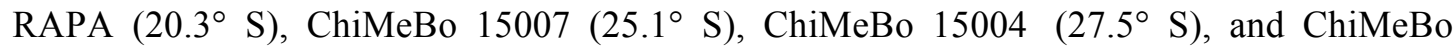
$15024\left(30.2^{\circ} \mathrm{S}\right)$ stations. Note that BHP concentrations from MOOMZ-2 (B) correspond to the sum of two size fractions $(>3.0 \mu \mathrm{m}$ and $0.3-3 \mu \mathrm{m})$. All other BHP concentrations are from $>0.7 \mu \mathrm{m}$ size fractions.

Figure 5. Relationship between the BHT II ratio and dissolved oxygen $(\mu \mathrm{mol} / \mathrm{kg})$ in samples from this study (Northern Chile; blue squares) and other OMZ systems as described by Sáenz et al. (2011). Note that samples from oxygenated waters below the OMZ were not included because they represent organic matter exported from within the OMZ. See main text for further details. 
Figure 6. Size fractioned BHP concentrations from 0.3-3 $\mu \mathrm{m}$ (B) and $>3 \mu \mathrm{m}(\mathrm{C})$ size fractions as compared to dissolved oxygen $(\mathrm{A} ; \mu \mathrm{mol} / \mathrm{kg})$ at MOOMZ-2 station $3\left(20.1^{\circ} \mathrm{S}\right)$.

Figure 7. Relative abundance (\%) of BHPs in surface sediments along a latitudinal transect from $23^{\circ} \mathrm{S}$ to $27^{\circ} \mathrm{S}$. Within each location, samples are organized in decreasing water depth from top to bottom.

Figure 8. Stable isotope and geochemical signatures in core GeoB 15016 at $27^{\circ} \mathrm{S}$ off the coast of northern Chile during Glacial Termination II (transition from MIS-6 to MIS-5). Top panel: LR04 Benthic stack $\delta^{18} \mathrm{O}$ data (grey dots and line) from Lisiecki and Raymo (2005), and $\delta^{18} \mathrm{O}$ from benthic foraminifera (black dots and line) in core GeoB15016 from Martínez-Méndez et al. (2013). Lower panel: $\delta^{15} \mathrm{~N}$ of bulk sediment (red dots and line) and BHT II ratio (blue dots and line) in core GeoB15016. 

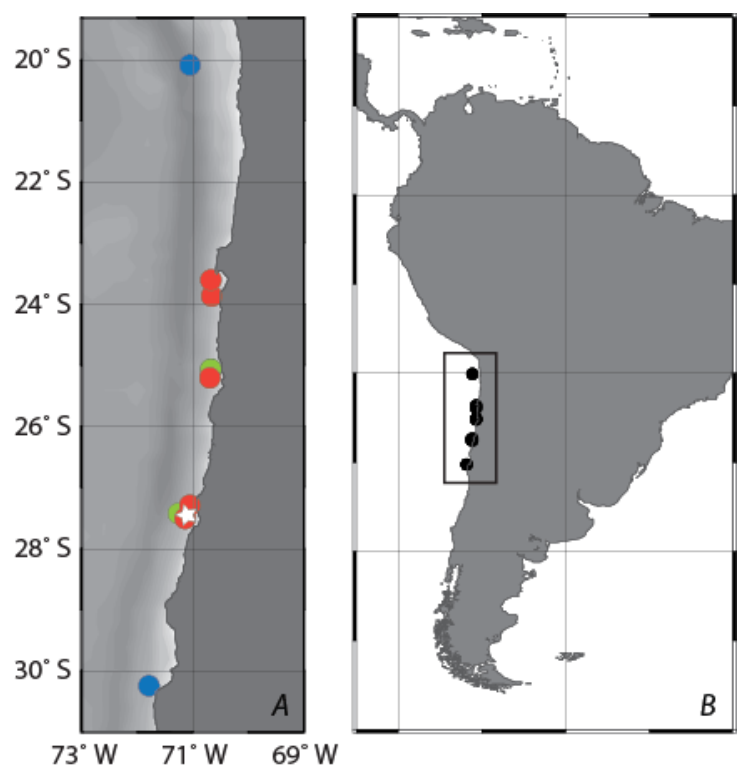

water column water column + surface sediments is buried sediment surface sediments

Figure 1
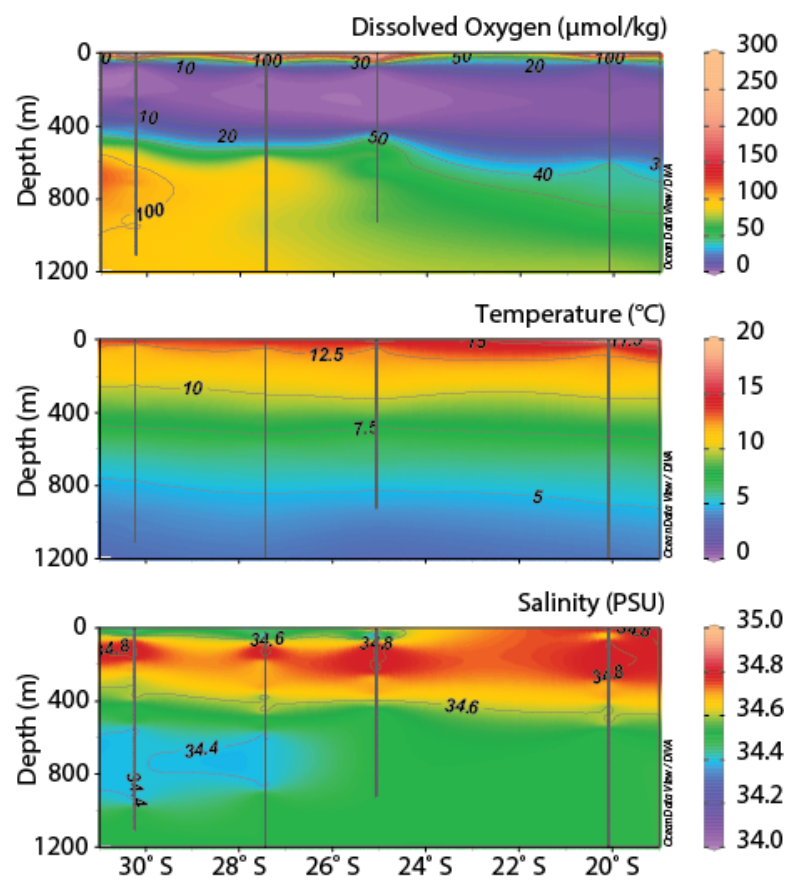

Figure 2 


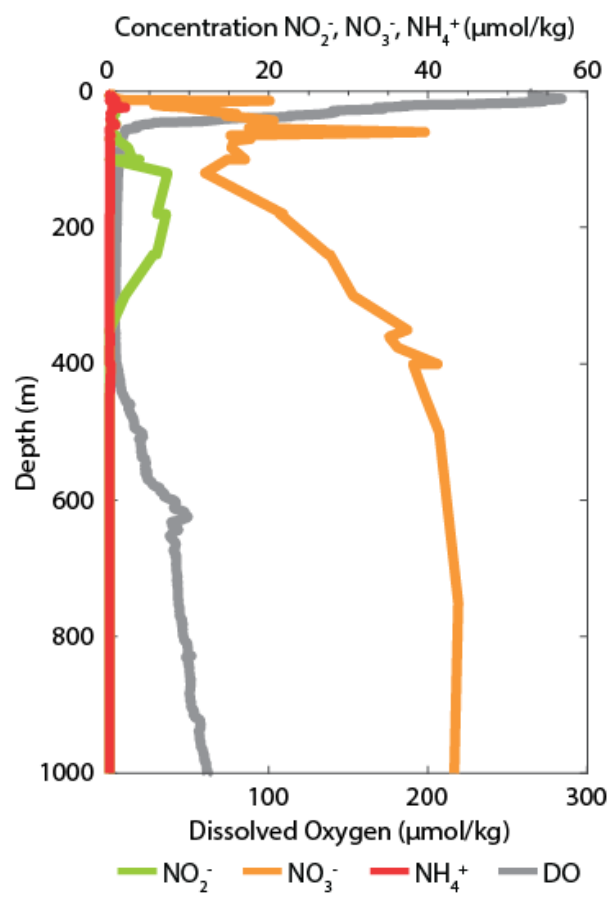

Figure 3
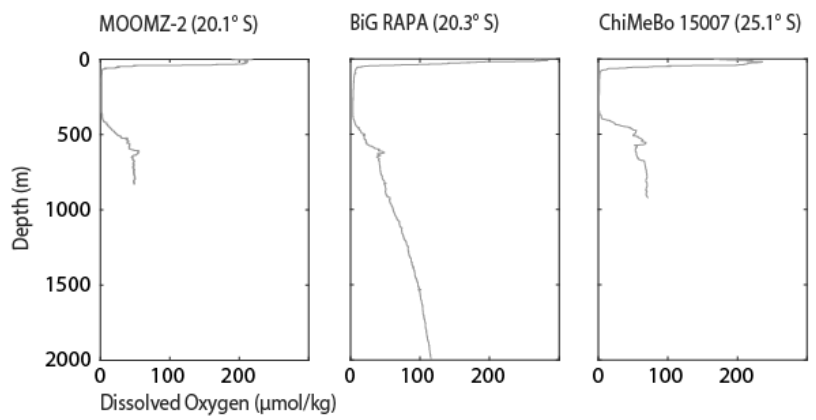

ChiMeBo $15004\left(27.5^{\circ} \mathrm{S}\right)$

ChiMeBo $15024\left(30.2^{\circ} \mathrm{S}\right)$
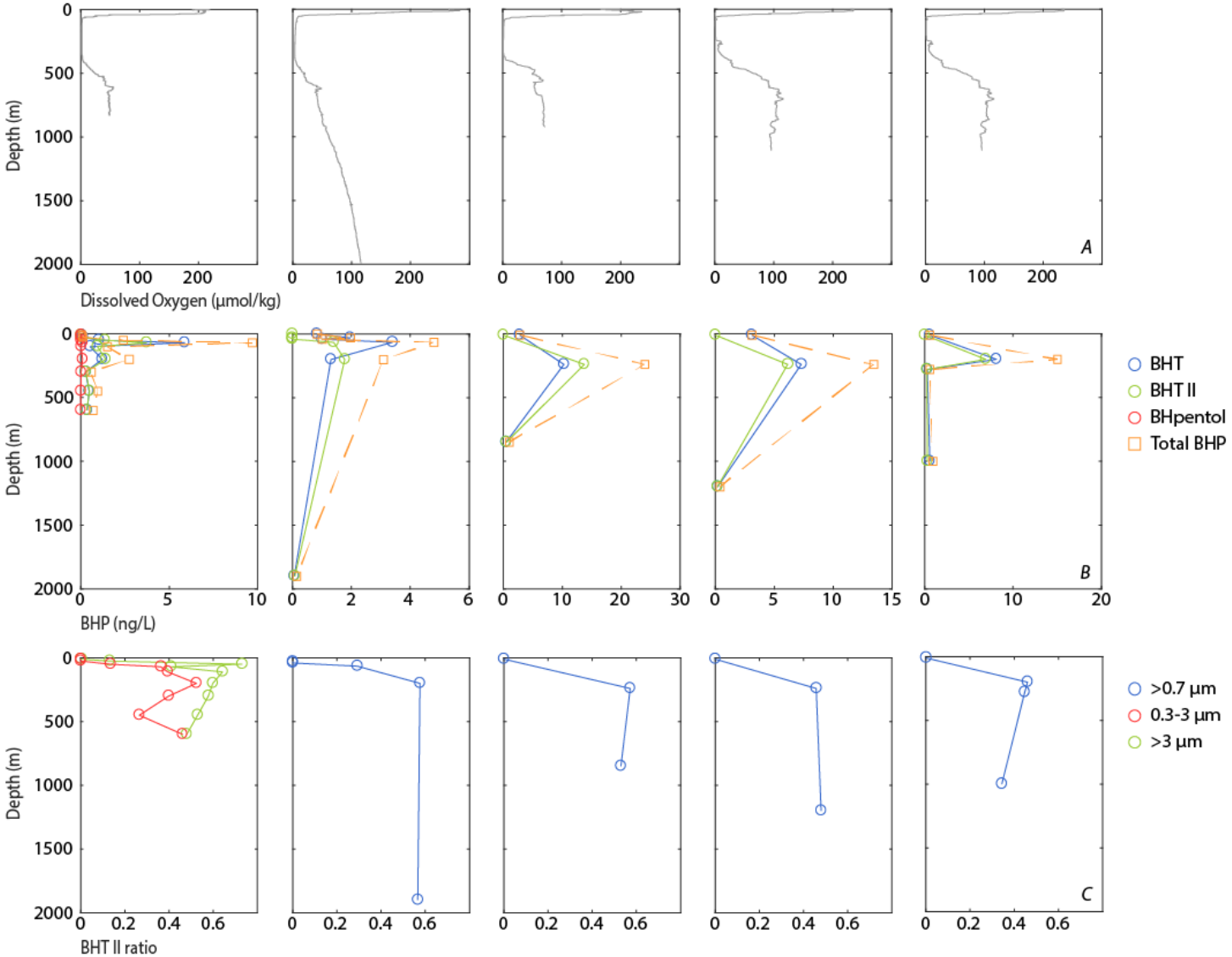

Figure 4 


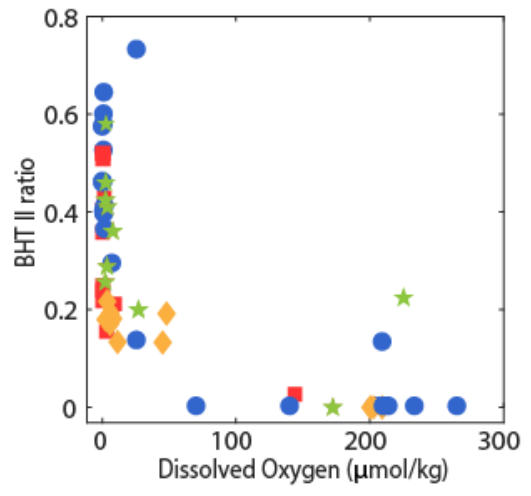

- Northern Chile

$\star$ Cariaco Basin

- Peru Margin

- Arabian Sea

Figure 5
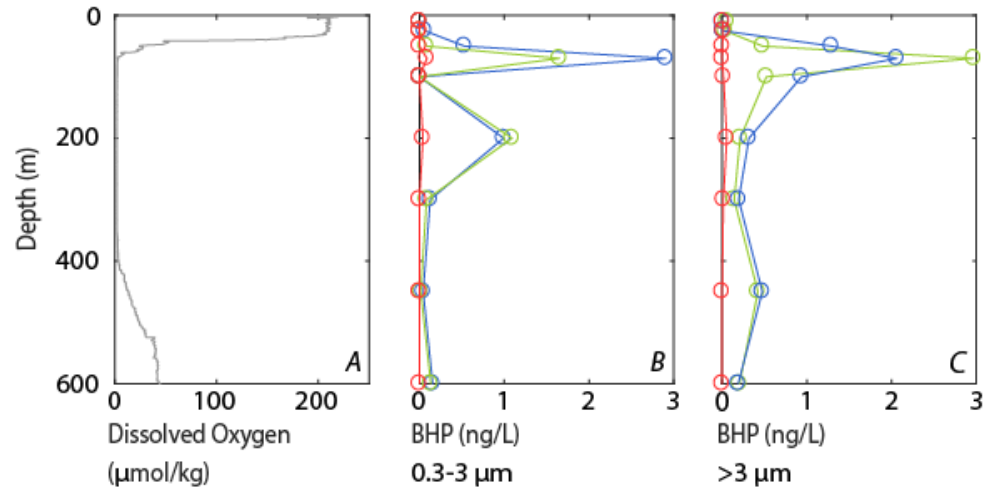

O BHT

- BHT II

- BHpentol

Figure 6

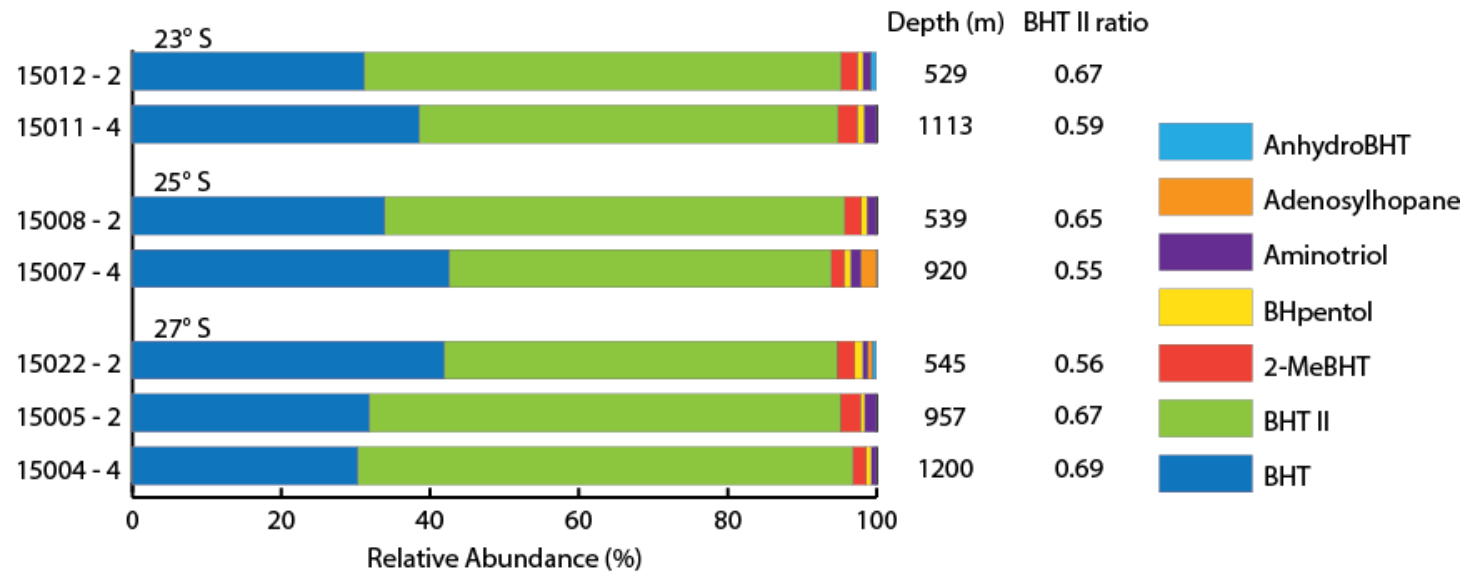

Figure 7 

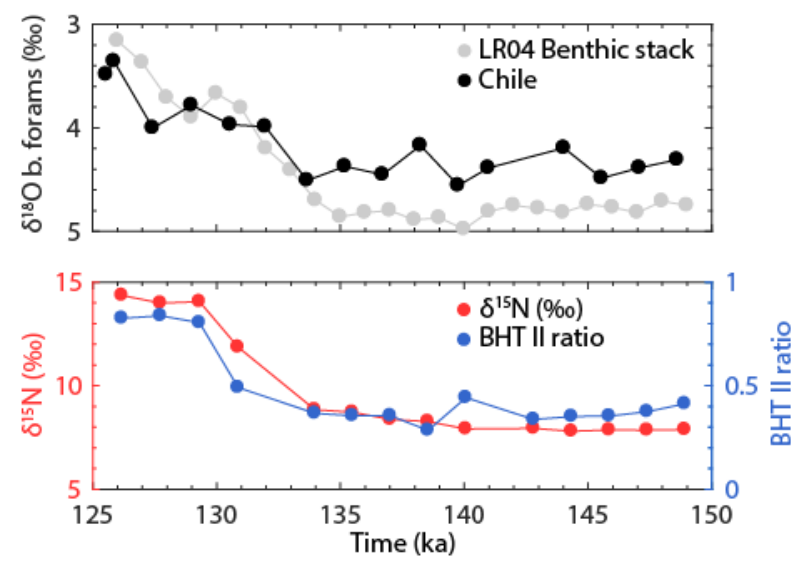

Figure 8 